\title{
Tribes query motives of knowledge databases
}

\section{Rex Dalton, Kelowna}

Attempts to set up databases of traditional knowledge are coming under attack from the very groups they are intended to benefit.

The World Intellectual Property Organization (WIPO), the Geneva-based body that promotes intellectual property rights, is keen to establish databases in which indigenous groups would record their cultural knowledge. Patent examiners would be encouraged to check a country's databases to see if a new idea, such as a plant-based medicine, is part of the traditional knowledge of that nation.

But delegates at the World's Indigenous Peoples conference, held on 16-19 October in Kelowna, British Columbia, described how some groups are concerned that the databases could be used to exploit their cultural heritage. Some Canadian tribes, for example, already have individual databases. But a national project, conducted on a shoestring budget by the Centre for Traditional Knowledge at the Canadian Museum of Nature in Ottawa, has suffered because indigenous groups are reluctant to make their databases available. The groups fear that secret traditions associated with plants or substances will be stolen, according to government officials working on the project.

Verna Miller, a custodian of traditional knowledge for the Nicola Tribal Association in Merritt, British Columbia, adds that her

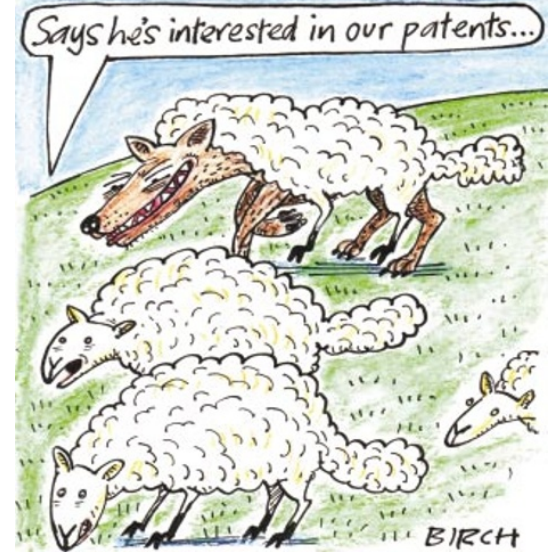

tribe guards its secrets so closely that even she doesn't know the password to its database only the tribal elders have it.

Overcoming such diffidence may be difficult. Advocates for indigenous groups fear that the databases could be used by Western companies and scientists aiming to profit from traditional knowledge. Controversial cases, such as the award and subsequent retraction of a US patent for a turmericbased wound remedy used in India (see Nature 389, 6; 1997), have generated widespread mistrust of patent organizations such as WIPO. "I can't think of a more inappropriate place for discussions on traditional knowledge," says Debra Harry, executive director of the Indigenous People's Council on Biocolonialism in Wadsworth, Nevada.

WIPO officials say they hope that involving indigenous groups in the development of the databases should help. The organization is consulting over 50 developed and developing countries about their requirement for databases and has set up a web portal for patent examiners, which already links to established databases in India and China. Two indigenous groups have also been granted observer status at meetings of the WIPO committee on traditional knowledge. "We want to make sure people are confident they have input to the process," says Tony Taubman, head of the organization's traditional knowledge division. "It would be fatuous to sit in Geneva and dream up a one-size-fits-all solution."

WIPO will next year publish reports on the databases and on other issues, which it hopes will clarify how traditional knowledge can be protected. But delegates at the Kelowna meeting are yet to be convinced that the idea will work. "I am highly sceptical that a national database will fly," says a Canadian scientist who works closely with indigenous groups. "At the heart of the debate is control of the knowledge. We have a long way to go. This takes commitment I haven't seen at a provincial or national level."

www.wipo.org

\section{Low stocks prompt calls for North Atlantic fishing ban}

\section{Quirin Schiermeier, Munich}

Unprecedented restrictions on commercial fishing in European Union (EU) waters have been proposed by leading fisheries scientists.

The Copenhagen-based International Council for the Exploration of the Sea (ICES), which provides scientific advice to fisheries-management authorities, says that all cod and haddock fisheries in the North Sea, the Skagerrak, the Irish Sea and off the western coast of Scotland should be closed for an undetermined period to allow stocks to recover.

The proposal has sent shock waves through the EU fishing industry, which would be in danger of substantial economic losses if prime fishing areas were closed. But scientists say that only drastic measures will save the stocks. According to the ICES assessment, carried out using data from fisheries laboratories in the council's 19 member states, the 'spawning stock biomass' (SSB) of cod and haddock in the northeast Atlantic are at new historic lows. The number of young fish surviving to adulthood is also the lowest on record.
Closure of parts of the most heavily fished oceans has long been espoused by conservation biologists as one way to rebuild stocks (see Nature 419, 664; 2002). EU member states often relax the stringent catch quotas recommended by ICES in order to appease their fishing industries, but the scale of the problem means that politicians must now accept large short-term losses, says Hans Lassen, a marine biologist who coordinates the work of groups that contribute to ICES reports.

Fisheries scientists also warn that the relatively stable cod and haddock catches in the northeast Atlantic in recent years are not reliable indicators of the abundance of fish in EU waters. They point to the Canadian Grand Banks fisheries off Newfoundland, which were closed in 1992 after the cod population collapsed. Canadian authorities failed to realize that intensified effort by fishing vessels was masking a decline in stocks. Only independent data gathered by research vessels can give an unbiased picture of the state of the stocks, the ICES report argues.
"It is an inescapable conclusion that the cod stocks around the United Kingdom are seriously depleted," says Robin Cook, chief executive of the Fisheries Research Services' Marine Laboratory in Aberdeen, UK. "Given that all management practices tried before have failed, closures are about all you can do in this rather extreme situation."

www.ices.dk

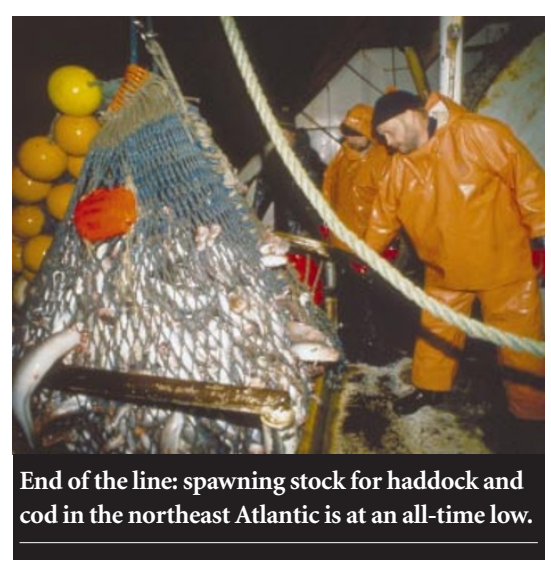

